\title{
Highly Selective Recognition of Cytosine over Uracil and Adenine by a Guanine Analog 2-N-Acetyl-3-deazaguanine in 2'-O-Methyl-RNA/RNA and DNA Duplexes
}

\author{
Kohji Seio ${ }^{1,3}$, Takeshi Sasami ${ }^{2,3}$, Akihiro Ohkubo ${ }^{2,3}$, Kaori Ando ${ }^{4}$, Mitsuo \\ Sekine S,3,* $^{2,3}$ \\ ${ }^{1}$ Frontier Collaborative Research Center, Tokyo Institute of Technology. ${ }^{2}$ Department of \\ Life Science, Tokyo Institute of Technology. ${ }^{3}$ CREST, JST. 4259 Nagatsuta-cho, \\ Yokohama, Japan 226-8501 and ${ }^{4}$ College of Education, University of the Ryukyus, \\ Okinawa 903-0213, Japan \\ msekine@bio.titech.ac.jp
}

Scheme S1

Experimental Procedure

General Methods S3

5'-O-(4, 4'-Dimethoxytrityl)-2'-O-methyl-3-deazaguanosine (4) S3

2- $\mathrm{N}$-Acetyl-5'-O-(4, 4'-dimethoxytrityl)-2'-O-methyl-3-deazaguanosine (5) S4

2- $\mathrm{N}$-Acetyl-5'-O-(4,4'-dimethoxytrityl)-2'-O-methyl-3-deazaguanosine 3'-(2-Cyanoethyl

$N, N$-diisopropylphosphoramidite) (2) S4

Synthesis of 2'-O-methyl-RNA incorporating 2- $\mathrm{N}$-acetyl-3-deazaguanine ----------------------------- S5

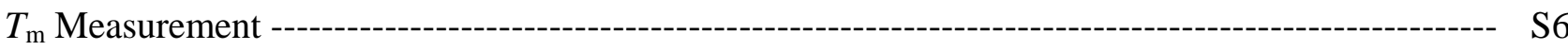

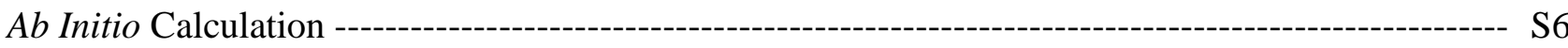

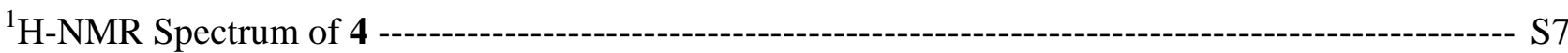

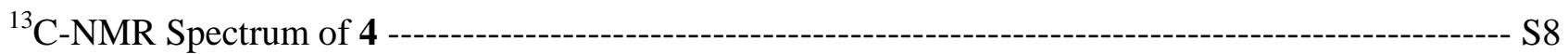

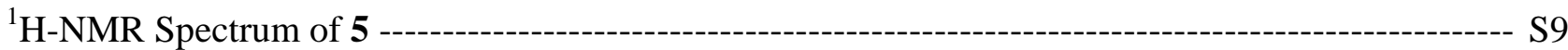

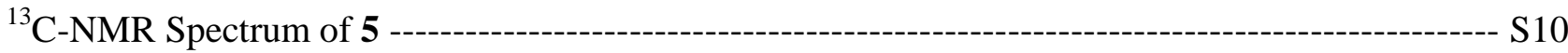

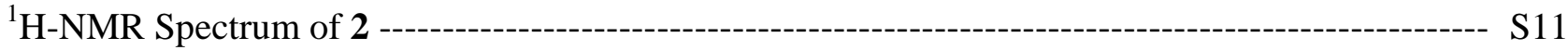

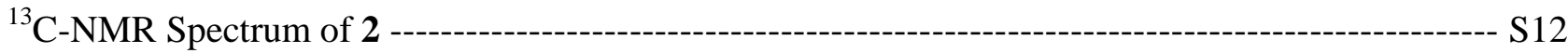

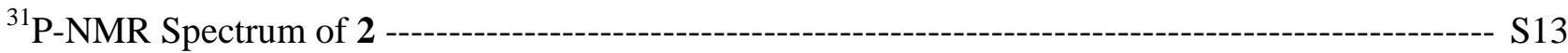




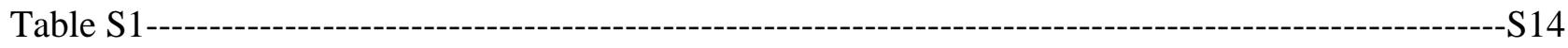

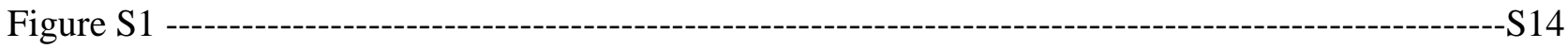

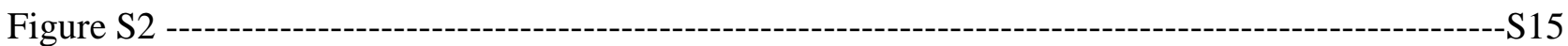

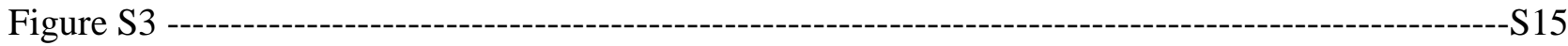

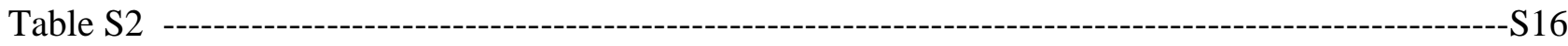


Scheme S1. Synthesis of phosphoramidite 2

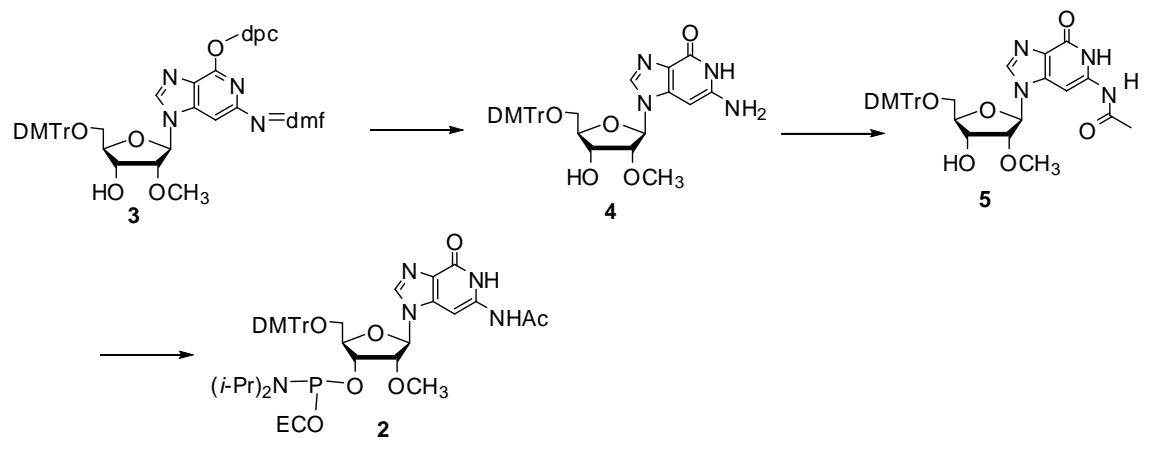

\section{Experimental Procedure}

General Methods. ${ }^{1} \mathrm{H},{ }^{13} \mathrm{C}$ and ${ }^{31} \mathrm{P}$ NMR spectra were obtained at 500, 126 and $203 \mathrm{MHz}$, respectively. The chemical shifts were measured from tetramethylsilane $(0.0 \mathrm{ppm})$ or DMSO- $d_{6}(2.49$ ppm) for ${ }^{1} \mathrm{H} \mathrm{NMR}, \mathrm{CDCl}_{3}$ (77.0 ppm), DMSO- $d_{6}$ (39.7 ppm) for ${ }^{13} \mathrm{C} \mathrm{NMR}$ and $85 \%$ phosphoric acid (0.0 ppm) for ${ }^{31} \mathrm{P}$ NMR.

5'-O-(4, 4'-Dimethoxytrityl)-2'-O-methyl -3-deazaguanosine (4). Compound 3 (Seio, K.; Sasami, T.; Tawarada, R.; Sekine, M. Nucleic Acids Res.2006, 34, 4324-4334., 290 mg, 0.34 mmol) was dissolved in $3.5 \mathrm{~mL}$ of conc. $\mathrm{NH}_{3}-40 \% \mathrm{CH}_{3} \mathrm{NH}_{2}$-pyridine $(2: 2: 1, \mathrm{v} / \mathrm{v} / \mathrm{v})$. The reaction mixture was stirred at $50{ }^{\circ} \mathrm{C}$ for $8 \mathrm{~h}$. The solvents were removed under reduced pressure, and the residue was dissolved in chloroform $(10 \mathrm{~mL})$. The solution was washed with sat. $\mathrm{NaHCO}_{3}(10 \mathrm{~mL})$. The organic layer was dried over $\mathrm{MgSO}_{4}$, filtered and concentrated under reduced pressure. The residue was chromatographed on a column of silica gel with chloroform-methanol (100:1-0:100, v/v). The fractions containing compound 4 were collected and concentrated under reduced pressure. The residue was dissolved in chloroform (10 $\mathrm{mL})$, and the contaminated silica gel was removed by washing with water $(10 \mathrm{~mL})$. The organic layer was dried over $\mathrm{MgSO}_{4}$, filtered and concentrated under reduced pressure to give $4(234 \mathrm{mg}, 73 \%)$ : ${ }^{1} \mathrm{H}$ NMR (DMSO-d6) $\delta 3.39(3 \mathrm{H}, \mathrm{s}), 3.72(6 \mathrm{H}, \mathrm{s}), 4.01(1 \mathrm{H}, \mathrm{d}, J=3.4 \mathrm{~Hz}), 4.14(1 \mathrm{H}, \mathrm{t}, J=4.9 \mathrm{~Hz}), 4.21(1 \mathrm{H}$, $\mathrm{t}, J=5.6 \mathrm{~Hz}), 5.27(1 \mathrm{H}, \mathrm{d}, J=6.4 \mathrm{~Hz}), 5.45(1 \mathrm{H}, \mathrm{s}), 5.56(2 \mathrm{H}, \mathrm{d}, J=8.3 \mathrm{~Hz}), 5.66(1 \mathrm{H}, \mathrm{d}, J=4.6 \mathrm{~Hz})$, $6.82-6.84(4 \mathrm{H}, \mathrm{m}) 7.18-7.32(9 \mathrm{H}, \mathrm{m}), 7.77(1 \mathrm{H}, \mathrm{s}), 10.32(1 \mathrm{H}, \mathrm{s} \mathrm{br}) ;{ }^{13} \mathrm{C}$ NMR ( DMSO-d6 ) $\delta 55.0$, 57.7, 63.5, 69.0, 70.3, 82.3, 83.4, 85.5, 86.0, 113.2, 123.0, 126.7, 127.7, 127.8, 129.7, 135.4, 135.4, 135.7, 142.7, 144.8, 147.9, 156.4, 158.0. MS m/z calcd for $\mathrm{C}_{33} \mathrm{H}_{35} \mathrm{~N}_{4} \mathrm{O}_{7}^{+}: 599.2506$, found 599.2550.

2-N-Acetyl-5'-O-(4,4'-dimethoxytrityl)-2'-O-methyl-3-deazaguanosine (5). Compound 4 (170 mg, $0.28 \mathrm{mmol}$ ) was rendered anhydrous by repeated coevaporation with dry pyridine and then with dry 
$\mathrm{CH}_{3} \mathrm{CN}$ and finally dissolved in dry $\mathrm{CH}_{3} \mathrm{CN}(2.8 \mathrm{~mL})$. To this solution was added hexamethyldisilazane (302 $\mu \mathrm{L}, 1.4 \mathrm{mmol}$ ). The resulting solution was stirred at room temperature for $2 \mathrm{~h}$. The solvent was removed under reduced pressure, and the residue was dissolved in dry pyridine $(2.8 \mathrm{~mL})$. To this solution was added acetyl chloride $(44 \mu \mathrm{L}, 0.62 \mathrm{mmol})$ at $0{ }^{\circ} \mathrm{C}$, and the reaction mixture was warmed to room temperature. After $2 \mathrm{~h}$, another portion of acetyl chloride $(20 \mu \mathrm{L}, 0.28 \mathrm{mmol})$ was added. The mixture was continued for additional $1 \mathrm{~h}$. The reaction was quenched by addition of water $(1 \mathrm{~mL})$. After $20 \mathrm{~min}$, conc. ammonia $(5 \mathrm{~mL})$ was added and the resulting solution was stirred for $11 \mathrm{~h}$. To this solution was added toluene $(10 \mathrm{~mL})$, and the solvents were removed under reduced pressure. The residue was dissolved in chloroform (6 mL), washed with sat. $\mathrm{NaHCO}_{3}(4 \mathrm{~mL})$, and washed with sat. $\mathrm{NaCl}(5 \mathrm{~mL})$. The organic layer was dried over $\mathrm{MgSO}_{4}$, filtered and concentrated under reduced pressure. The residue was chromatographed on a column of silica gel with chloroform-methanol (100:2, v/v) to give 5 (120 mg, 65\%): ${ }^{1} \mathrm{H}$ NMR (DMSO-d6) $\delta 2.09$ ( 3H, s ), 3.14 - 3.20 ( 2 H, m ), 3.41 ( 3H, s), $3.71(6 \mathrm{H}, \mathrm{s}), 4.06(1 \mathrm{H}$, $\mathrm{dd}, J=5.1 \mathrm{~Hz}, J=8.6 \mathrm{~Hz}), 4.20(1 \mathrm{H}, \mathrm{t}, J=4.7 \mathrm{~Hz}), 4.24(1 \mathrm{H}, \mathrm{dd}, J=5.4 \mathrm{~Hz}, J=11.5 \mathrm{~Hz}), 5.31(1 \mathrm{H}, \mathrm{d}$, $J=6.4 \mathrm{~Hz}), 5.86(1 \mathrm{H}, \mathrm{d}, J=4.4 \mathrm{~Hz}), 6.45(1 \mathrm{H}, \mathrm{s}$ br), $6.80-6.83(4 \mathrm{H}, \mathrm{m}), 7.15-7.29(9 \mathrm{H}, \mathrm{m}), 8.07(1 \mathrm{H}$, s), $10.54\left(1 \mathrm{H}, \mathrm{s}\right.$ br), $11.28\left(1 \mathrm{H}, \mathrm{s}\right.$ br); ${ }^{13} \mathrm{C}$ NMR (DMSO-d6) $\delta$ 23.6, 55.0, 57.8, 63.3, 69.0, 82.6, 83.7, 85.5, 86.5, 113.1, 126.6, 127.6, 127.6, 127.8, 129.6, 135.3, 135.4, 138.0, 139.9, 144.7, 155.4, 158.0, 170.3. MS $\mathrm{m} / \mathrm{z}$ calcd for $\mathrm{C}_{35} \mathrm{H}_{37} \mathrm{~N}_{4} \mathrm{O}_{8}{ }^{+}: 641.2611$, found 641.2642 .

\section{2- $N$-Acetyl-5'-O-(4,4'-dimethoxytrityl)-2'-O-methyl-3-deazaguanosine}

3'-(2-Cyanoethyl $N, N$-diisopropylphosphoramidite) (2). Compound 5 (119 mg, $0.19 \mathrm{mmol}$ ) was rendered anhydrous by repeated coevaporation with dry $\mathrm{CH}_{2} \mathrm{Cl}_{2}$, and finally dissolved in dry $\mathrm{CH}_{2} \mathrm{Cl}_{2}(1.9 \mathrm{~mL})$. To this solution was added $N, N$-diisopropylethylamine $(54 \mu \mathrm{L}, 0.32 \mathrm{mmol})$ and chloro(2-chyanoethoxy)( $N$, $N$-diisopropylamino)phosphine $(59 \mu \mathrm{L}, 0.27 \mathrm{mmol})$ at $0{ }^{\circ} \mathrm{C}$. The reaction mixture was warmed to room temperature and stirred for $2 \mathrm{~h}$. The reaction was quenches by addition of water $(2 \mathrm{~mL})$, and the solution was diluted with ethyl acetate $(5 \mathrm{~mL})$. The solution was washed five times with sat. $\mathrm{NaHCO}_{3}(5 \mathrm{~mL})$. The organic layer was dried over $\mathrm{MgSO}_{4}$, filtered, and concentrated under reduced pressure. The residue was chromatographed on recycle HPLC to give $2(47 \mathrm{mg}, 30 \%):{ }^{1} \mathrm{H}$ NMR $\left(\mathrm{CDCl}_{3}\right) \delta 1.03-1.05(4 \mathrm{H}, \mathrm{m})$, $1.17-1.29(9 \mathrm{H}, \mathrm{m}), 1.65(2 \mathrm{H}, \mathrm{s}), 2.02(3 \mathrm{H}, \mathrm{m}), 2.37,2.68(2 \mathrm{H}, \mathrm{m}), 3.36-3.67(7 \mathrm{H}, \mathrm{m}), 3.77(6 \mathrm{H}, \mathrm{m})$, 3.87 - $3.98(1 \mathrm{H}, \mathrm{m}), 4.13-4.16(1 \mathrm{H}, \mathrm{m}), 4.32$ - $4.38(1 \mathrm{H}, \mathrm{m}), 4.47-4.50(1 \mathrm{H}, \mathrm{m}), 5.85(1 \mathrm{H}, \mathrm{m}), 6.80(4 \mathrm{H}$, m), 7.20 - $7.91(9 \mathrm{H}, \mathrm{m}), 7.96(1 \mathrm{H}, \mathrm{m}), 10.21(1 \mathrm{H}, \mathrm{s}$ br $), 11.80(1 \mathrm{H}, \mathrm{s} \mathrm{br}) ;{ }^{13} \mathrm{C} \mathrm{NMR}\left(\mathrm{CDCl}_{3}\right) \delta 0.1,20.2$, $20.3,20.5,24.7,24.8,24.8,29.8,43.3,43.4,43.5,43.6,55.4,57.9,58.1,58.6,59.1,59.2,62.9,63.2,70.7$, 70.8, 71.5, 71.6, 76.9, 82.3, 82.5, 83.7, 84.1, 84.3, 84.7, 86.9, 87.0 87.4, 87.8, 113.4, 117.5, 118.1, 127.9, 
128.0, 128.1, 128.2, 128.3, 130.2, 130.3, 135.4, 135.5, 138.3, 138.7, 138.8, 141.1, 141.3, 144.4, 144.6, 157.4, 158.8, 170.3; ${ }^{31} \mathrm{P}$ NMR $\left(\mathrm{CDCl}_{3}\right) \delta 151.6,152.2$. MS m/z calcd for $\mathrm{C}_{44} \mathrm{H}_{53} \mathrm{~N}_{6} \mathrm{NaO}_{9} \mathrm{P}^{+}: 863.3509$, found 863.3466 .

\section{Synthesis of 2'-O-methyl-RNA incorporating 2- $\mathrm{N}$-acetyl-3-deazaguanine}

The 2'- $O$-methylated oligonucleotides incorporating 2- $N$-acetyl-2'- $O$-methyl-3-deazaguanosine, 5'-CGGC $\left[\mathrm{a}^{2} \mathrm{c}^{3} \mathrm{G}\right] \mathrm{AGGAG-3'}$ was synthesized as follows. First, the 3'-half sequence 5'-AGGAG-3' was synthesized on an Applied Biosystems 394 automated DNA/RNA synthesized using the standard 1.0 $\mu \mathrm{mol}$ phosphoramidite cycle of detritylation, coupling, capping and iodine oxidation. The CPG support was removed from the cartridge column and placed on a glass syringe having a glass filter. Then the $\mathrm{a}^{2} \mathrm{c}^{3} \mathrm{G}$ residue was introduced to the $5^{\prime}$-terminal by use of 20 equiv of the phosphoramidite 2 and 80 equiv of $1 \mathrm{H}$-tetrazole by use of $250 \mu \mathrm{L}$ of dry $\mathrm{CH}_{3} \mathrm{CN}-\mathrm{CH}_{2} \mathrm{Cl}_{2}(2: 1, \mathrm{v} / \mathrm{v})$. The coupling time was $5 \mathrm{~min}$. After this manual procedure, the CPG support was placed to the cartridge column and the remaining 5'-half sequence, 5'-CGGC-3' was synthesized by use of the DNA synthesizer. The cleavage of the synthesized 5'-DMTr-oligonucleotide from the solid support and the deprotection of the nucleobases were carried out by treatment with $28 \%$ aqueous ammonia at room temperature for $24 \mathrm{~h}$. The solution was evaporated under reduced pressure at room temperature to remove ammonia, and the residue was diluted with $0.1 \mathrm{M}$ ammonium acetate $(50 \mathrm{~mL})$. The solution was placed on the $\mathrm{C} 18$ cartridge column and the failure sequences were eluted by use of $10 \% \mathrm{CH}_{3} \mathrm{CN} / 0.1 \mathrm{M}$ ammonium acetate as an eluent. After being washed with $0.1 \mathrm{M}$ ammonium acetate and water, the column was treated with aqueous $2 \%$ TFA to remove DMTr group, washed with $0.1 \mathrm{M}$ ammonium acetate and water. The target oligonucleotide was eluted by use of $20 \% \mathrm{CH}_{3} \mathrm{CN}$ /water and the fractions containing the target were lyophilized to give the crude oligonucleotide. Pure material was obtained by being purified on a anion-exchange HPLC by use of $0-50 \%$ gradient of $1 \mathrm{M} \mathrm{NaCl}$ in $25 \mathrm{mM}$ sodium phosphate- $10 \% \mathrm{CH}_{3} \mathrm{CN}$. The salts were removed by use of the $\mathrm{C} 18$ cartridge column to give the pure oligonucleotide after being lyophilized to dryness. The yield of the pure material was $5 \%$ by assuming the molar extinction coefficent of the 2'-O-methyl-5'-CGGC $\left[\mathrm{a}^{2} \mathrm{c}^{3} \mathrm{G}\right] \mathrm{AGGAG}-3$ ' was identical to that of 5'-r(CGGCGAGGAG)-3'. The structure was confirmed by MALDI-TOF Mass spectroscopy. calcd for $\mathrm{C}_{111} \mathrm{H}_{143} \mathrm{~N}_{45} \mathrm{O}_{67} \mathrm{P}_{9}[\mathrm{M}-\mathrm{H}]^{-}$: 3456.7, found 3456.6 
$\boldsymbol{T}_{\mathbf{m}}$ Measurement. Each oligonucleotide was dissolved in $10 \mathrm{mM}$ sodium phosphate (pH 7.0) containing $100 \mathrm{mM} \mathrm{NaCl}$ and $0.1 \mathrm{mM}$ EDTA so that the final concentration of each oligonucleotide became $2 \mu \mathrm{M}$. The solution was separated into quartz cells $(10 \mathrm{~mm})$ and incubated at $85^{\circ} \mathrm{C}$. After $10 \mathrm{~min}$ the solution was cooled to $5{ }^{\circ} \mathrm{C}$ at the rate of $0.5^{\circ} \mathrm{C} / \mathrm{min}$ and heated to $85^{\circ} \mathrm{C}$ at the same rate. During this annealing and melting, the absorption at $260 \mathrm{~nm}$ was recorded and used to draw UV-melting curves. The $T_{\mathrm{m}}$ value was calculated as the temperature that gave the maximum of the first derivative of the UV-melting curve.

Ab Initio Calculation. The geometries of 1-methyl-uracil, 1-methyl-cytosine, 9-methyl-guanine and 9-methyl-2- $N$-acetyl-3-deazaguanine were optimized at the HF/6-31G** level by use of Gaussian 03 software. ${ }^{1}$ The orientation of the acetyl group of $2-N$-acetyl-3-deazaguanine was determined by the geometry optimization starting from the structures having different dihedral angles of N1-C2-N2- $\mathrm{C}_{(=0) \text { acetyl }}$ and $\mathrm{C} 2-\mathrm{N} 2-\mathrm{C}_{(=\mathrm{O}}$, acetyl) $-\mathrm{C}_{(\mathrm{sp} 3 \text {, acetyl). }}$ During the minimization, no geometry constraint was applied. The initial structures of the base pairs were generated by placing the two geometry-optimized isolated bases on a plane keeping the distances between the hydrogen-bonded $\mathrm{O}$ and $\mathrm{H}$, and $\mathrm{N}$ and $\mathrm{H}$ within 1.96-1.99 $\AA$. The geometries of the base pair was optimized at the HF/6-31G** level and the final energies were calculated at the MP2/6-31G** level. In all cases, the optimized structures and the transition structure were confirmed by the frequency analyses.

The thermal and the zero-point energy corrections were taken from the frequency analyses data. The Gibbs free energy was calculated at $298.15 \mathrm{~K}$ as the sum of electronic energy, zero-point energy, translational energy, rotational energy, vibration energy, RT and -TS where R, T and S are the gas constant, temperature and entropy, respectively.

The base pairing energy $(\Delta \mathrm{E})$ was defined as

$$
\Delta \mathrm{E}=\mathrm{E}(\text { base pair })-\{\mathrm{E}(\text { isolated base } 1)+\mathrm{E}(\text { isolated base } 2)\} .
$$

The basis set superposition errors (BSSE) were estimated by the counterpoise method. ${ }^{2}$

1) Frisch, M. J.; Trucks, G. W.; Schlegel, H. B.; Scuseria, G. E.; Robb, M. A.; Cheeseman, J. R.; Montgomery, J. A., Jr.; Vreven, T.; Kudin, K. N.; Burant, J. C.; Millam, J. M.; Iyengar, S. S.; Tomasi, J.; Barone, V.; Mennucci, M.; Cossi, M.; Scalmani, G.; Rega, N.; Petersson, G. A.; Nakatsuji, H.; Hada, M.; Ehara, M.; Toyota, K.; Fukuda, R.; Hasegawa, J.; Ishida, M.; Nakajima, T.; Honda, Y.; Kitao, O.; Nakai, H.; Klene, M.; Li, X.; Knox, J. E.; Hratchian, H. P.; Cross, J. B.; Adamo, C.; Jaramillo, J.; Gomperts, R.; Stratmann, R. E.; Yazyev, O.; Austin, A. J.; Cammi, R.; Pomelli, C.; Ochterski, J. W.; Ayala, P. Y.; Morokuma, K, Voth, G. A.; Salvador, P., Dannenberg, J. J.; Zakrezwski, V. G.; Dapprich, S.; Daniels, A. D.; Strain, M. C.; Farkas, O.; Malick, D. K.; Rabuck, A. D.; Raghavachari, K.; Foresman, J. B.; Ortiz, J. V.; Cui, Q.; Baboul, A. G.; Clifford, S.; Cioslowski, J.; Stefanov, B. B.; Liu, G.; Liashenko, A.; Piskorz, P.; Komaromi, I.; Martin, R. L.; Fox, D. J.; Keith, T.; Al-Laham, M. A.; Peng, C. Y.; Nanayakkara, A.; Challacombe, M.; Gill, P. M. W.; Johnson, B.; Chen. W.; Wong, M. W.; Gonzalez, C.; Pople, J. A. Gaussian 03, Revision C.02; Gaussian, Inc., Pittsburgh PA, 2003.

2) Boys, S. F.; Bernardi, F. Mol. Phys. 1970, 19, 553-566. 


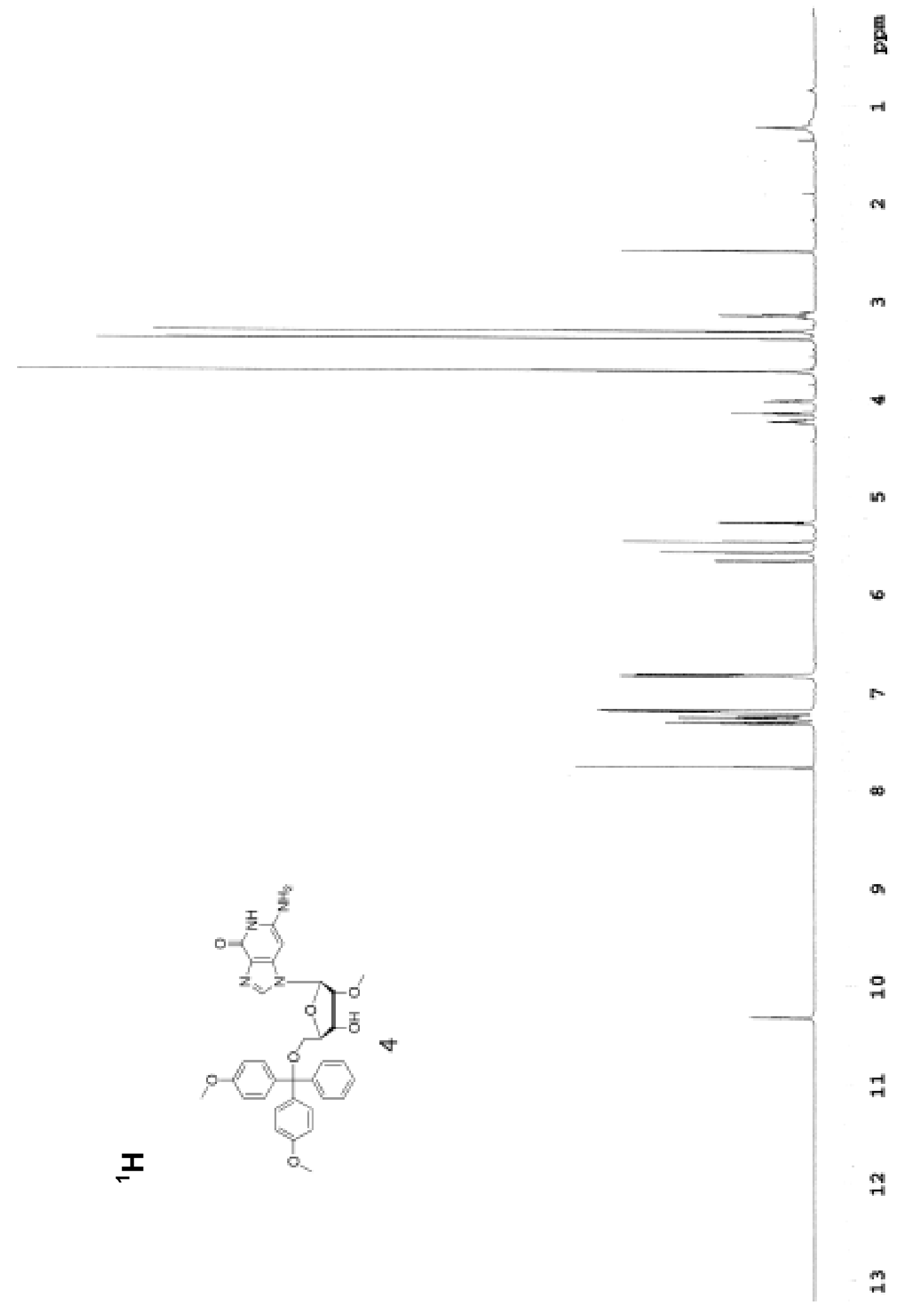




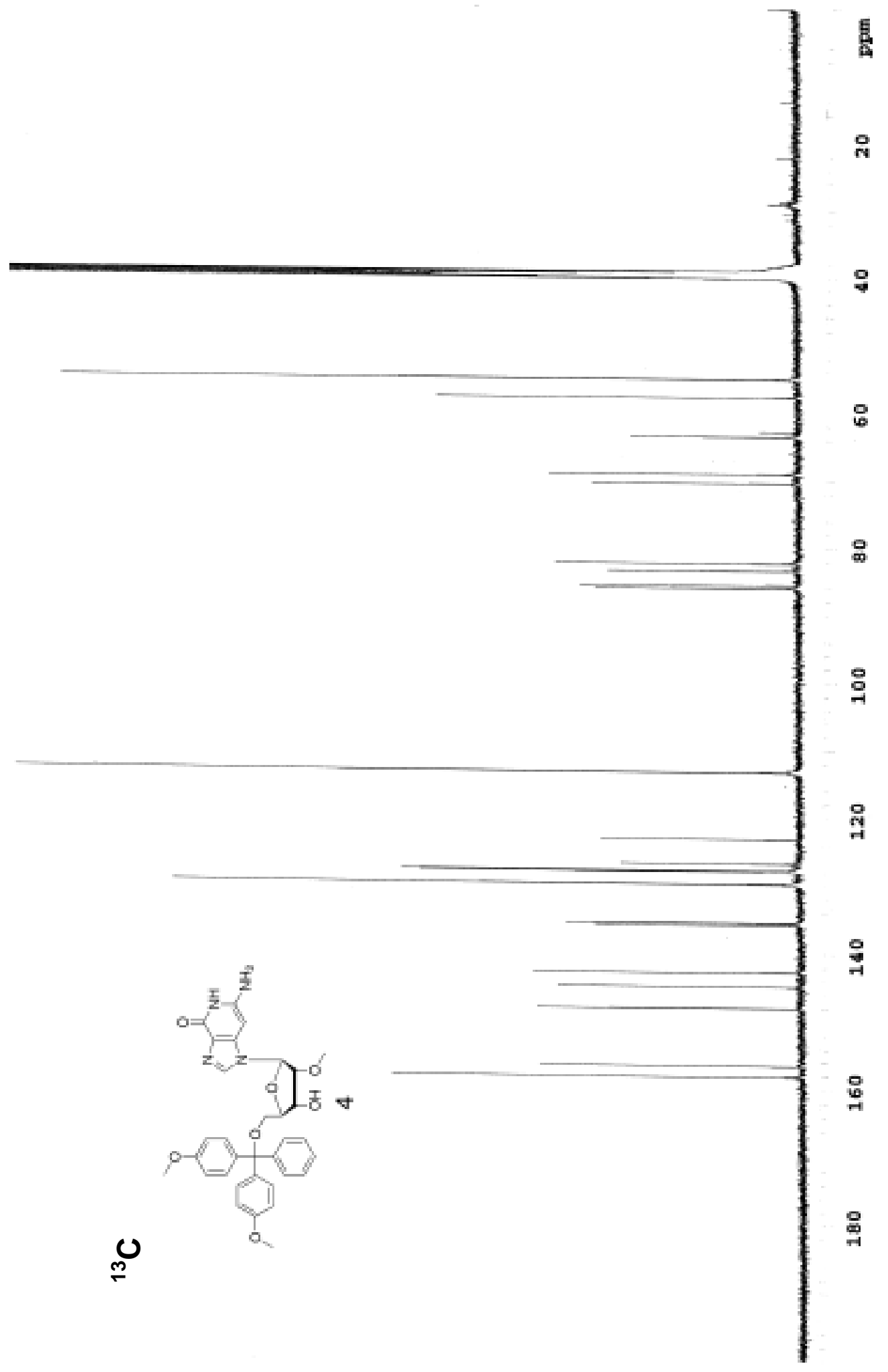




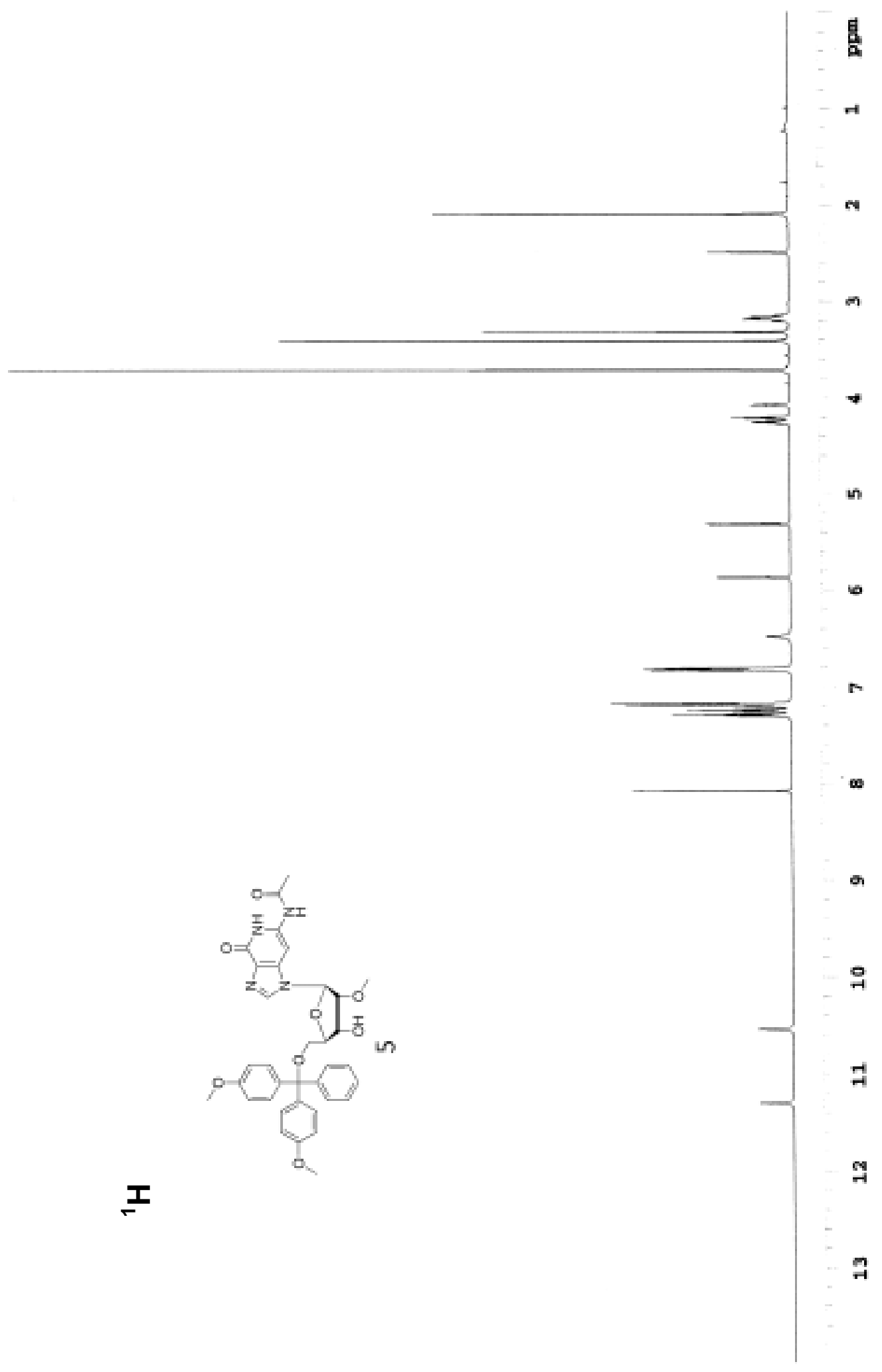




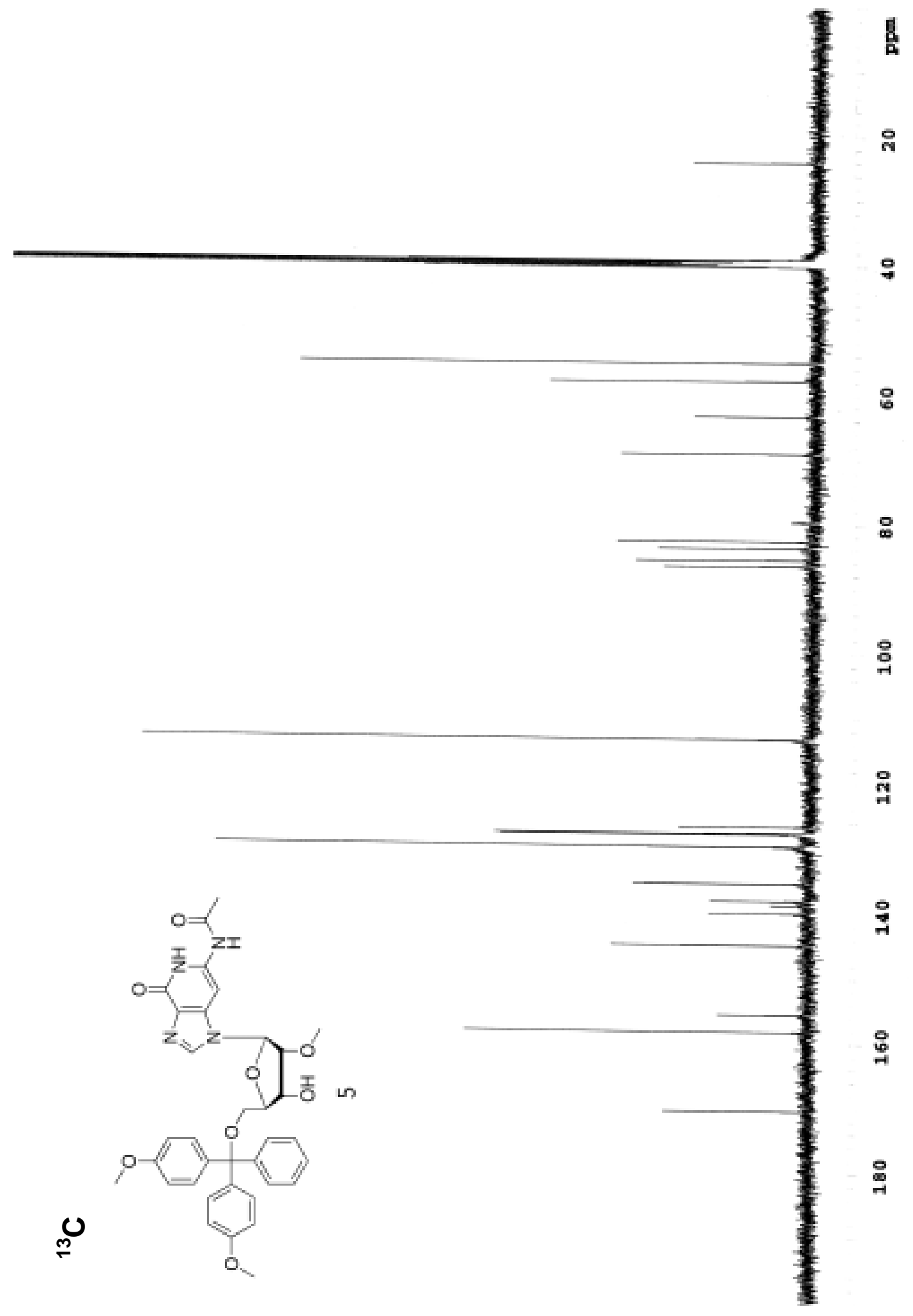




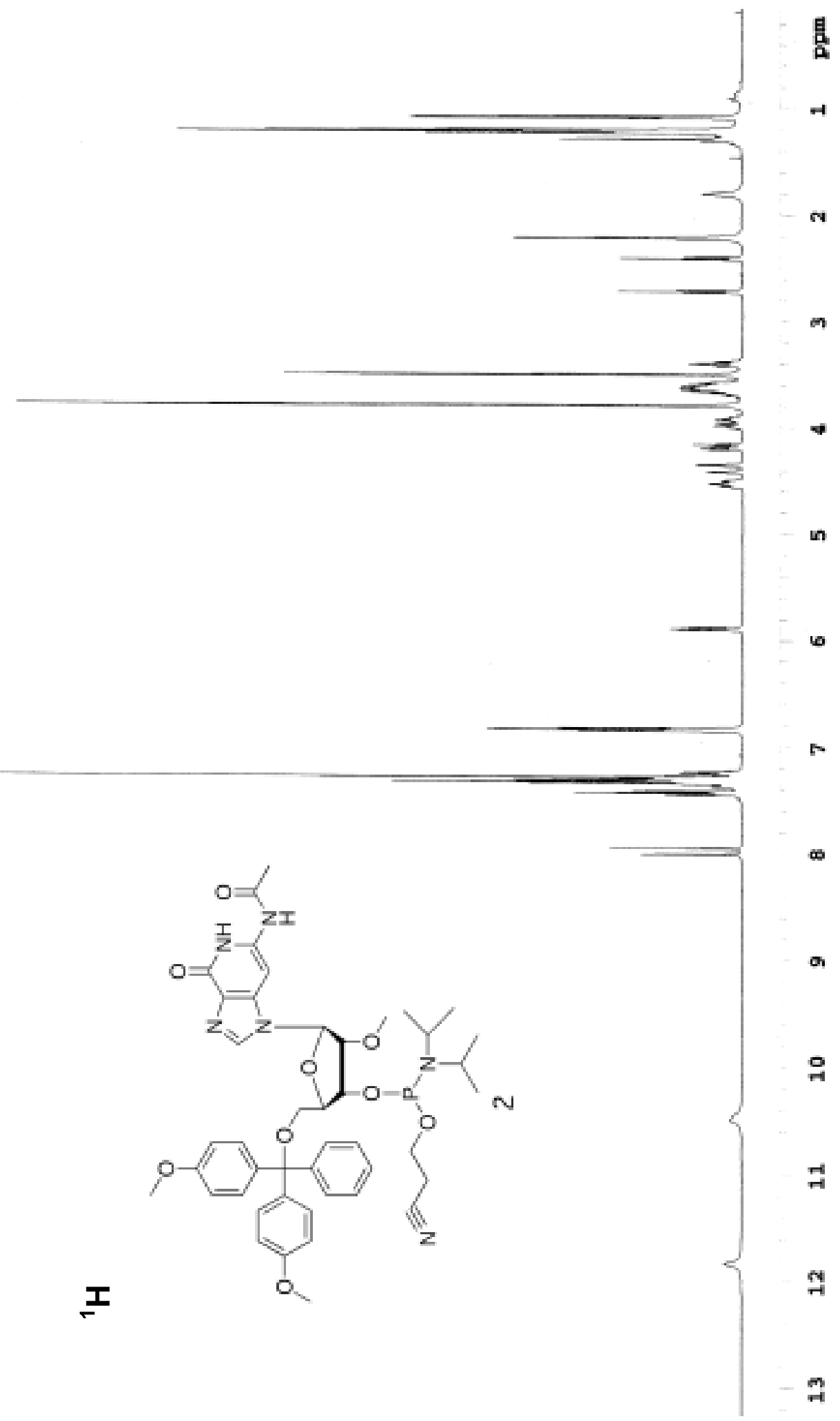




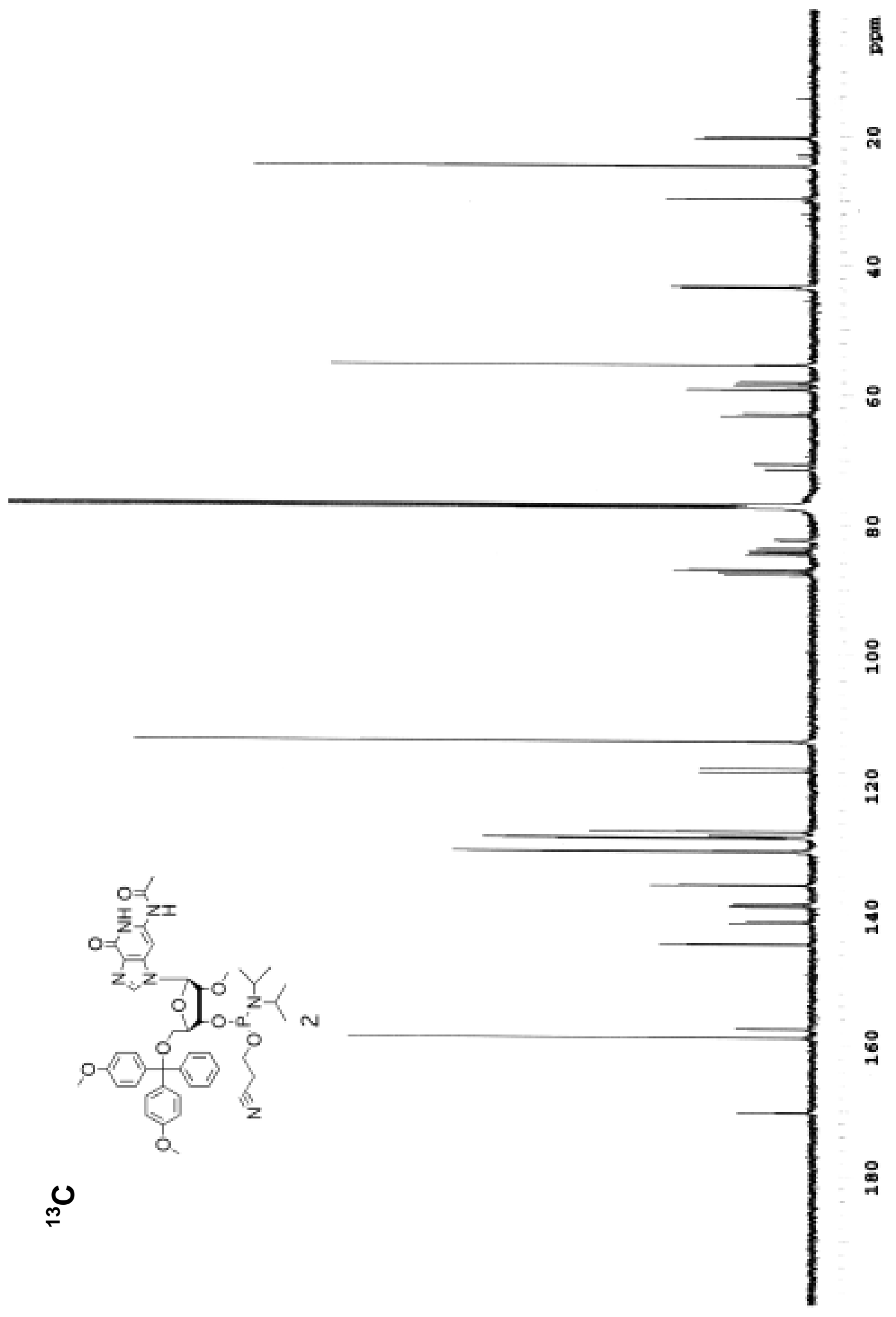




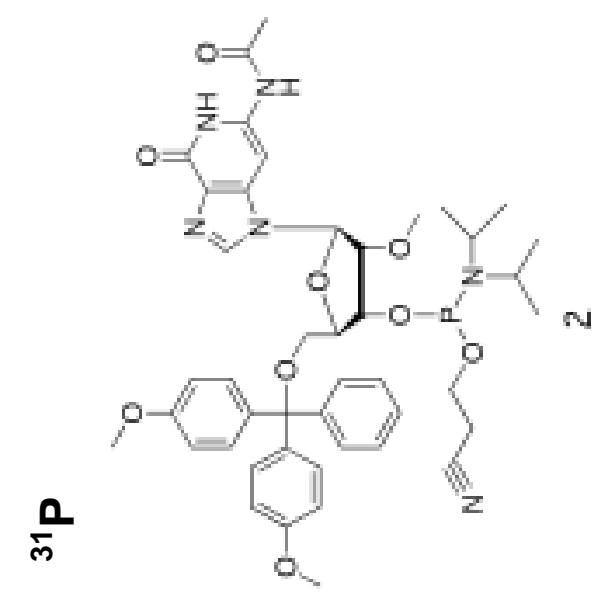

:

이

:

국

국

뭄

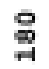


Table S1. Base pairing energies $(\Delta \mathrm{E}, \mathrm{kcal} / \mathrm{mol})$ after BSSE corrections calculated at the $\mathrm{MP} 2 / 6-31 \mathrm{G}^{* *} / / \mathrm{HF} / 6-31 \mathrm{G}^{\star *}$ level.

\begin{tabular}{ccc}
\hline & $\mathrm{C}$ & $\mathrm{U}$ \\
\hline $\mathrm{a}^{2} \mathrm{c}^{3} \mathrm{G}$ (open form) & -28.5 & -15.5 \\
guanine & -24.5 & -13.1 \\
$\Delta \Delta \mathrm{E}^{*}$ & -1.7 & -0.1 \\
\hline$* \Delta \Delta \mathrm{E}=\left\{\Delta \mathrm{E}\left(\mathrm{a}^{2} \mathrm{c}^{3} \mathrm{G}_{\text {open form }}\right)+2.3\right\}-\Delta \mathrm{E}$ (guanine)
\end{tabular}

Figure S1. The structures and energies of 'closed form', 'open form', the transition structure (TS) and the amide rotamer. The energy differences $(\Delta \mathrm{E})$ were calculated at $\mathrm{MP} 2 / 6-31 \mathrm{G} * * / / \mathrm{HF} / 6-31 \mathrm{G}^{* *}$ without the thermal corrections. The thermal corrections and the zero-point energies to the free energies at 298.15 $\mathrm{K}$ were taken from the frequency calculations at the $\mathrm{HF} / 6-31 \mathrm{G}^{* *}$ and added to the internal energies at the MP2/6-31G** level to obtain the Gibbs free energies $(\Delta \mathrm{G})$. The $\Delta \mathrm{E}$ and $\Delta \mathrm{G}$ are the relative values from those of the closed form.

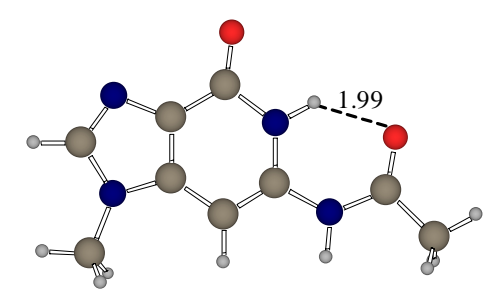

(Z)-N-acetyl closed form

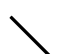

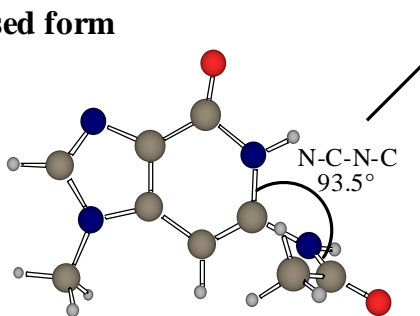

TS

$\Delta \mathrm{E}=+4.2 \mathrm{kcal} / \mathrm{mol}$

$\Delta \mathrm{G}=+4.7 \mathrm{kcal} / \mathrm{mol}$ 
Figure S2. The structures and energies of the base pairs. The BSSE corrected energy differences $(\Delta \mathrm{E})$ were calculated at MP2/6-31G**//HF/6-31G** without the thermal corrections. The thermal corrections and the zero-point energies to the free energies at $298.15 \mathrm{~K}$ were taken from the frequency calculations at the HF/6-31G** and added to the BSSE corrected energies at the MP2/6-31G** level to obtain the Gibbs free energies $(\Delta \mathrm{G})$.

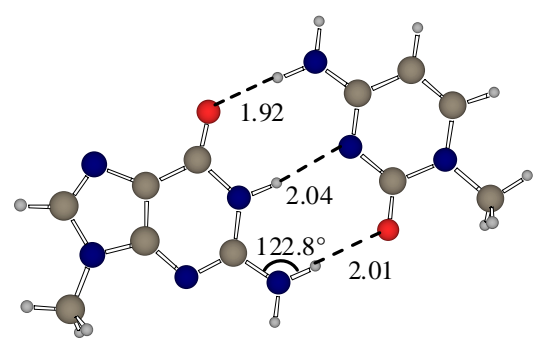

G-C

$\Delta \mathrm{E}=-24.5 \mathrm{kcal} / \mathrm{mol}$ $\Delta \mathrm{G}=-11.2 \mathrm{kcal} / \mathrm{mol}$

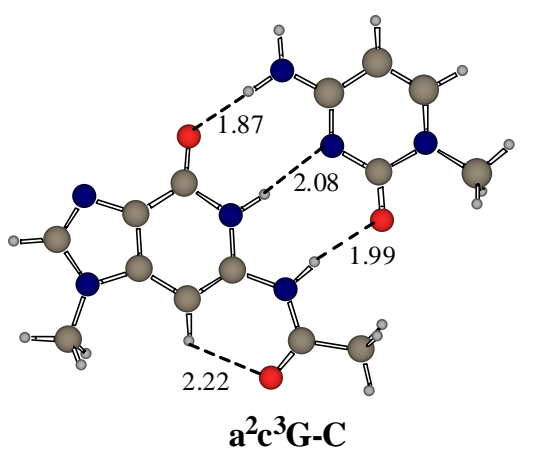

$\Delta \mathrm{E}=-28.5 \mathrm{kcal} / \mathrm{mol}$ $\Delta \mathrm{G}=-13.6 \mathrm{kcal} / \mathrm{mol}$ base pairing energy $\quad \begin{aligned} & \Delta \mathrm{E}=-13.1 \mathrm{kcal} / \mathrm{mol} \\ & \Delta \mathrm{G}=-1.3 \mathrm{kcal} / \mathrm{mol}\end{aligned}$
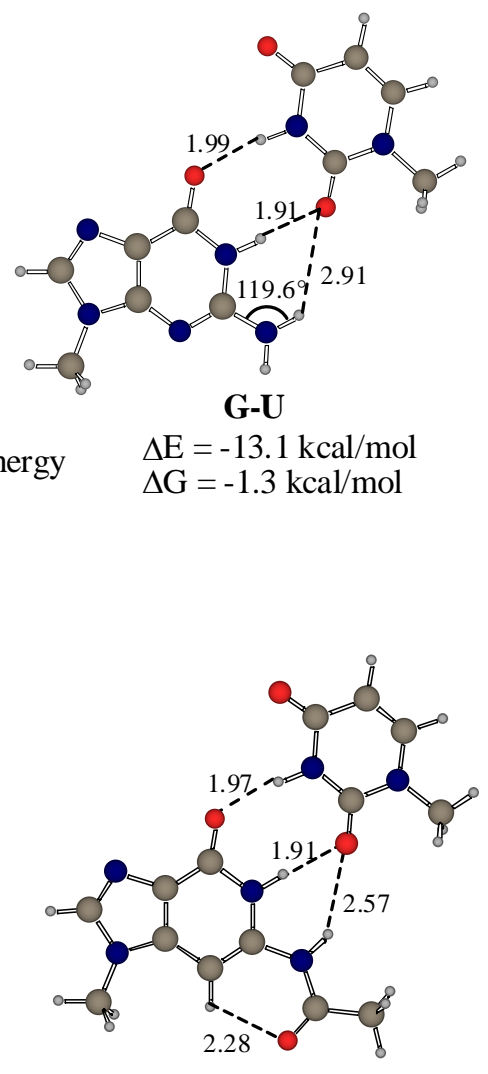

$\mathbf{a}^{2} \mathbf{c}^{3} \mathbf{G}-\mathbf{U}$

$\Delta \mathrm{E}=-15.5 \mathrm{kcal} / \mathrm{mol}$ $\Delta \mathrm{G}=-2.6 \mathrm{kcal} / \mathrm{mol}$

Figure S3. Geometries of mismatch base pairs containing a guanine derivative with uracil and adenine ( $G$ : $R=H, X=N$; $a^{2} c^{3} G: R=A c, X=C H$ ).

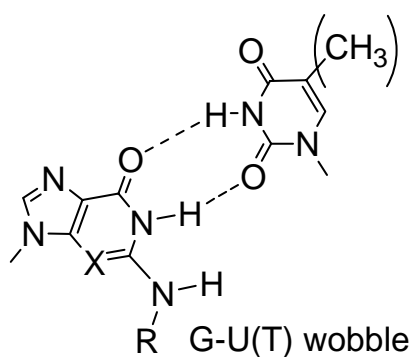

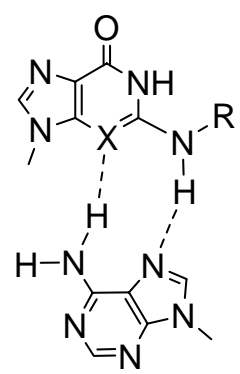

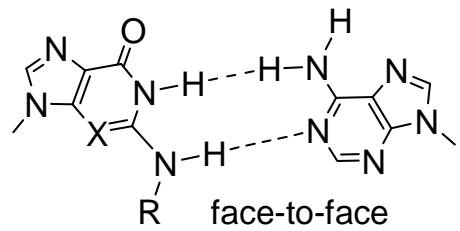

R' G-U(T) wobble

sheared 
Table S2. Coordinates and the energies (Hartree) of the structures shown in Figure S2 and Figure S3. $\mathrm{E}$ is the electronic energy calculated at MP2/6-31G** $\mathrm{G}$ is the Gibbs free energy at $298.15 \mathrm{~K}$.

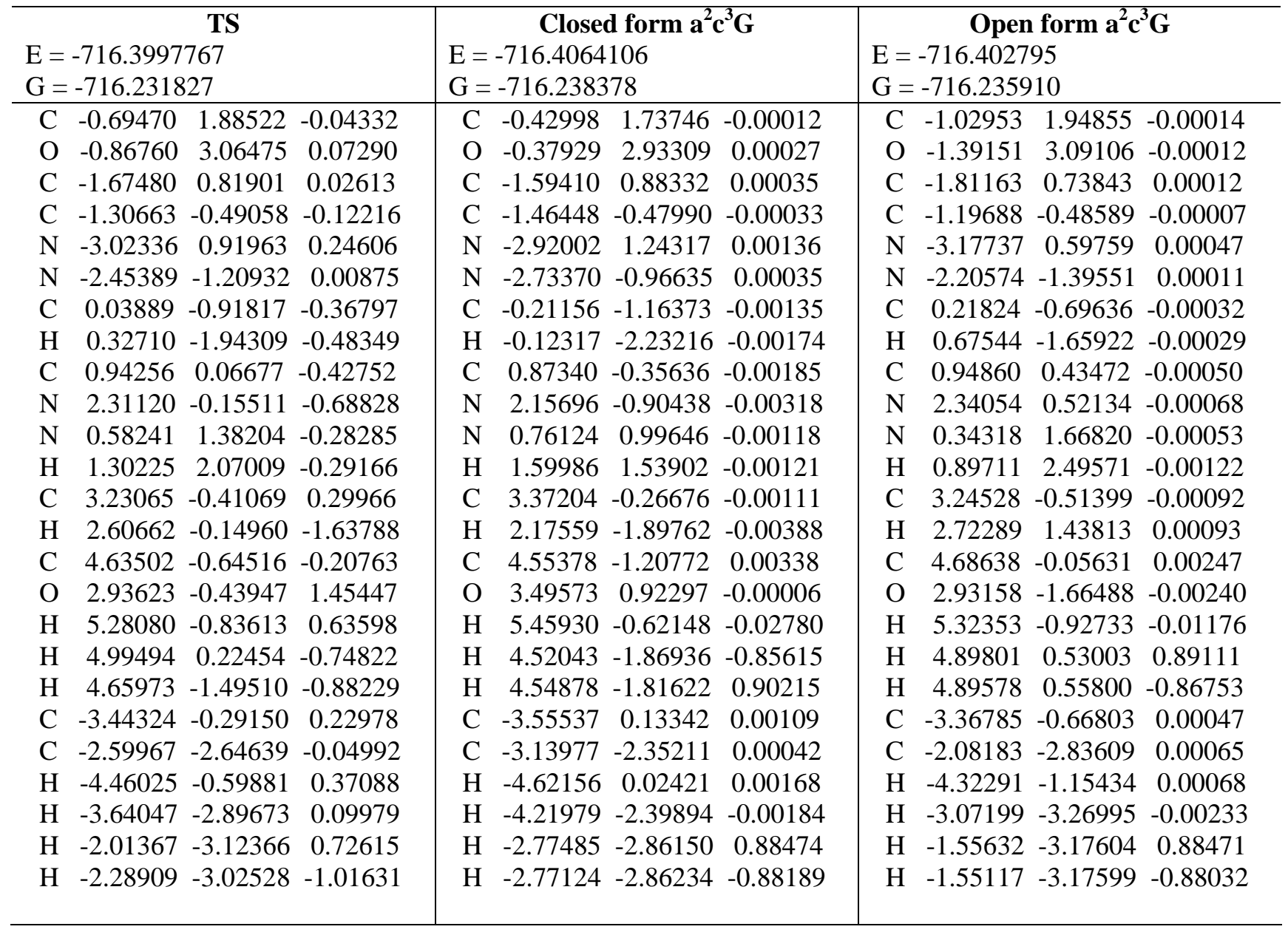


Table S2 (continued).

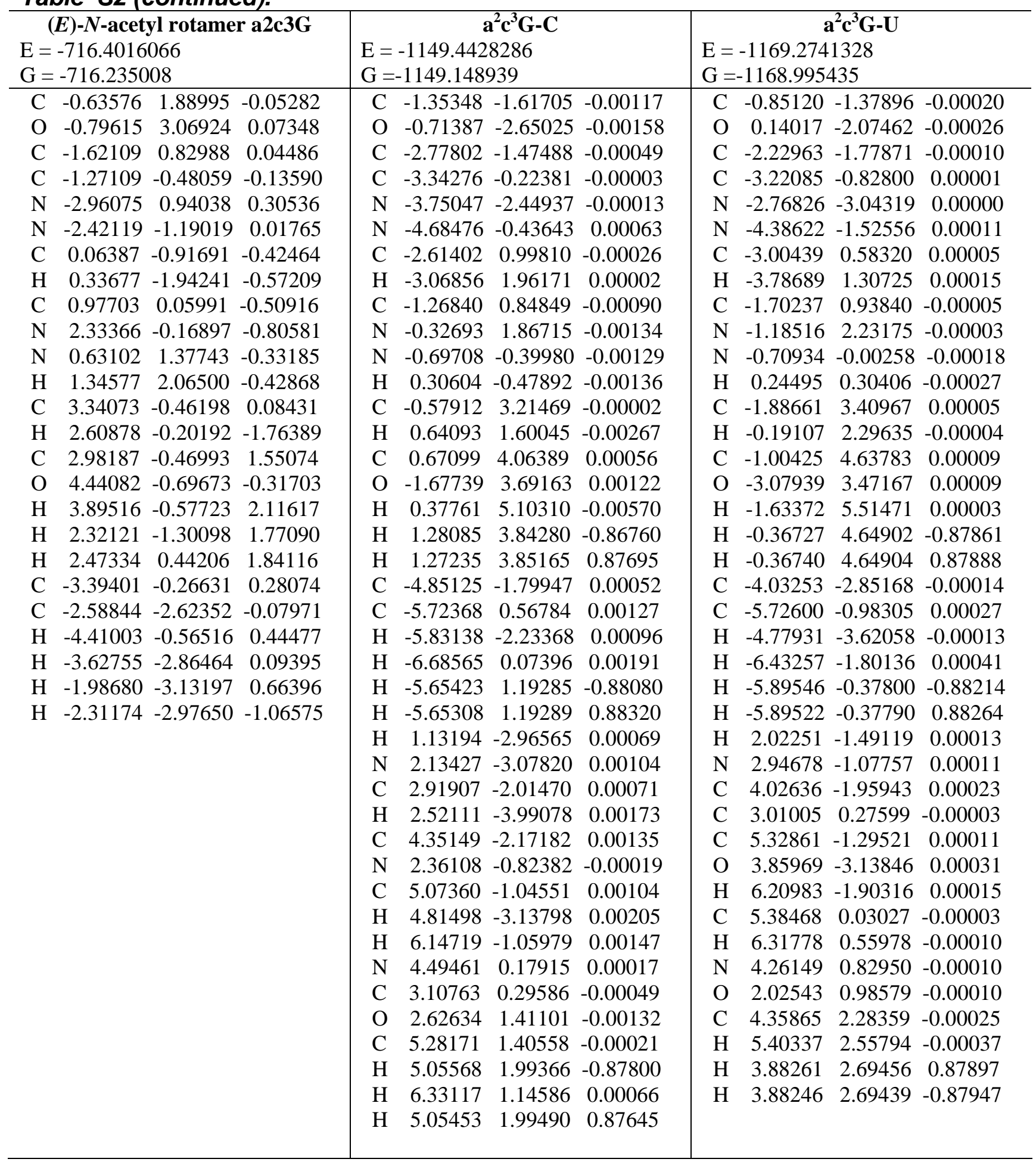


Table S2 (continued).

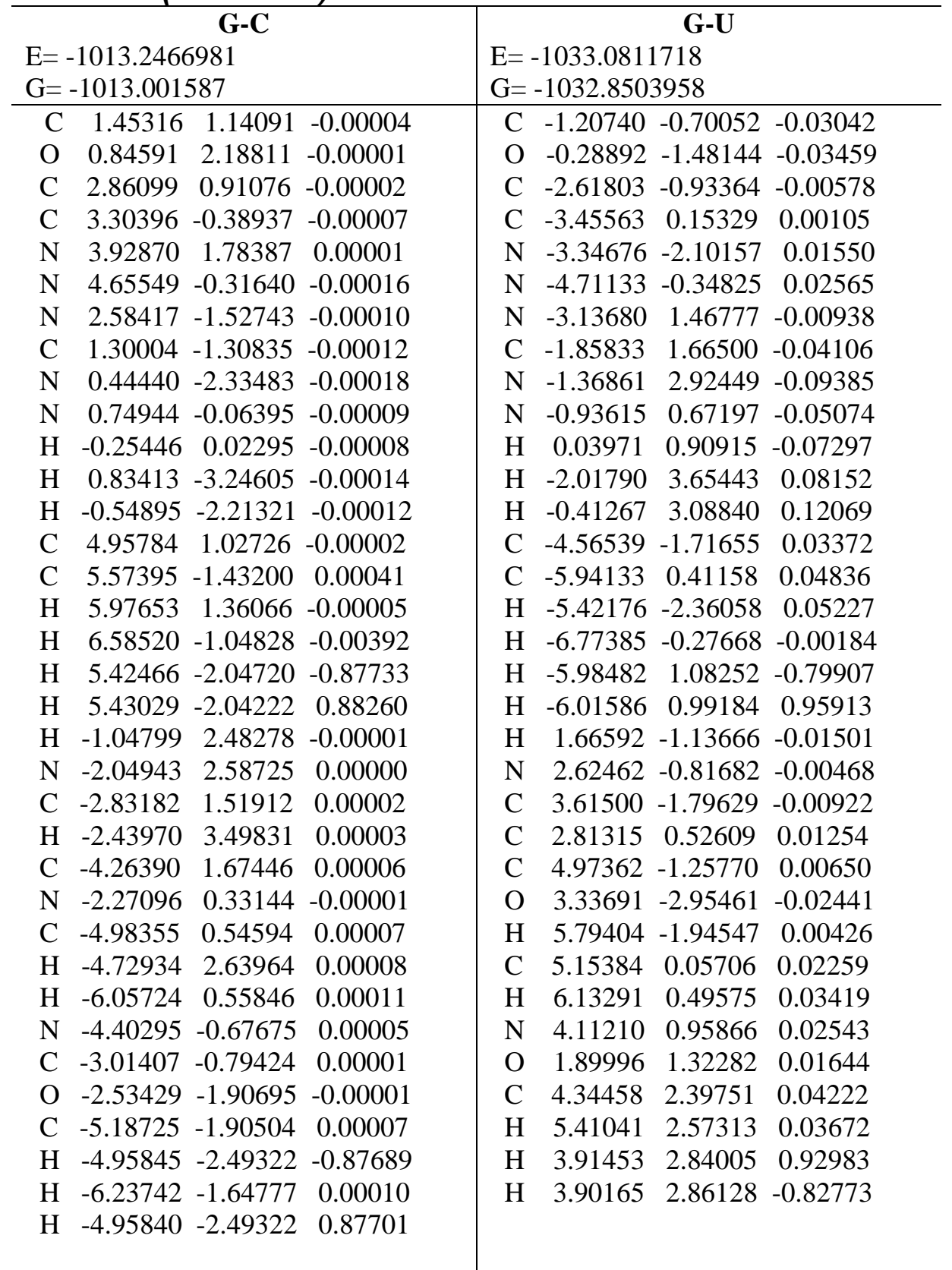

